\title{
Understanding the impact of mountain landscapes on water balance in the upper Heihe River watershed in northwestern China
}

\author{
Jia QIN ${ }^{1,2 *}$, YongJian DING ${ }^{1,2}$, JinKui $W^{1,2}$, MingJie GAO ${ }^{1}$, ShuHua $\mathrm{YI}^{1}$, ChuanCheng ZHAO ${ }^{1}$, \\ Baisheng YE ${ }^{1}$, Man $\mathrm{LI}^{1,2}$, ShengXia WANG ${ }^{1,2}$

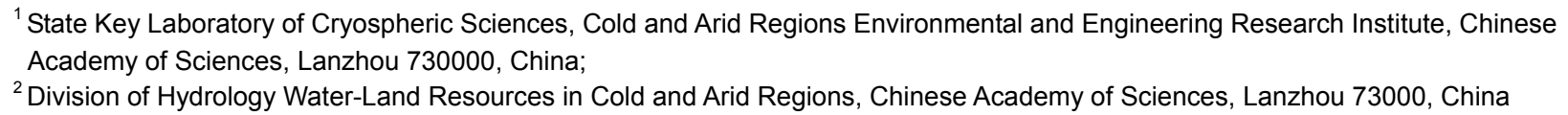

\begin{abstract}
Estimating the impact of mountain landscape on hydrology or water balance is essential for the sustainable development strategies of water resources. Specifically, understanding how the change of each landscape influences hydrological components will greatly improve the predictability of hydrological responses to mountain landscape changes and thus can help the government make sounder decisions. In the paper, we used the VIC (Variable Infiltration Capacity) model to conduct hydrological modeling in the upper Heihe River watershed, along with a frozen-soil module and a glacier melting module to improve the simulation. The improved model performed satisfactorily. We concluded that there are differences in the runoff generation of mountain landscape both in space and time. About $50 \%$ of the total runoff at the catchment outlet were generated in mid-mountain zone $(2,900-4,000$ $\mathrm{m}$ asl), and water was mainly consumed in low mountain region $(1,700-2,900 \mathrm{~m}$ asl) because of the higher requirements of trees and grasses. The runoff coefficient was 0.37 in the upper Heihe River watershed. Barren landscape produced the largest runoff yields $(52.46 \%$ of the total runoff) in the upper Heihe River watershed, followed by grassland $(34.15 \%)$, shrub $(9.02 \%)$, glacier $(3.57 \%)$, and forest $(0.49 \%)$. In order to simulate the impact of landscape change on hydrological components, three landscape change scenarios were designed in the study. Scenario 1,2 and 3 were to convert all shady slope landscapes at 2,000-3,300 m, 2,000-3,700 m, and $2,000-4,000 \mathrm{~m}$ asl respectively to forest lands, with forest coverage rate increased to $12.4 \%, 28.5 \%$ and $42.0 \%$, respectively. The runoff at the catchment outlet correspondingly declined by $3.5 \%, 13.1 \%$ and $24.2 \%$ under the three scenarios. The forest landscape is very important in water conservation as it reduced the flood peak and increased the base flow. The mountains as "water towers" play important roles in water resources generation and the impact of mountain landscapes on hydrology is significant.
\end{abstract}

Keywords: mountain landscape; runoff modeling; water balance; VIC model; Heihe River watershed

Citation: Jia QIN, YongJian DING, JinKui WU, MingJie GAO, ShuHua YI, ChuanCheng ZHAO, BaiSheng YE, Man LI, ShengXia WANG. 2013. Understanding the impact of mountain landscapes on water balance in the upper Heihe River watershed in northwestern China. Journal of Arid Land, 5(3): $366-384$.

Water shortages cause serious problems in arid areas, which rarely receive precipitation, such as northwestern China. The arid region of China roughly consists of two parts; the mountainous and plain regions. Mountainous regions play a role in collecting, storing and delivering water while plain regions consume most of the water in a basin (Viviroli et al., 2003; Messerli et al., 2004; Viviroli and Weingartner, 2004). The water resources of oases in the plain region are mainly supplied by mountain runoff (Cheng and Zhao,

\footnotetext{
*Corresponding author: Jia QIN (E-mail: qinjia418@163.com) Received 2012-10-30; revised 2012-12-15; accepted 2012-12-18

(C) Xinjiang Institute of Ecology and Geography, Chinese Academy of Sciences, Science Press and Springer-Verlag Berlin Heidelberg 2013
} 
2008). A clear understanding of the process of how water is collected and stored and an understanding of the changes in runoff in mountainous areas is helpful in developing and planning the use of water resources (Wang et al., 2005), and can effectively guide people's production and living in piedmont oasis regions (Cheng and Zhao, 2008).

The mountain landscapes in northwestern China are mainly composed of glaciers, grassland, forestland, shrubland and barren. After interception, consumption and redistribution in different landscapes, precipitation and glacial meltwater from mountains flow together and finally form the surface runoff. Each landscape has different impacts on the hydrological process in mountains and the water balance components vary in different landscapes. Understanding the impact of mountain landscapes on water balance and assessing the mountain landscape changes on hydrology is a basis for watershed management and ecological restoration. The existing researches about hydrological process of mountain landscapes mainly include evaluation of spatial responses of hydrological consequences to different landscape distributions, comparison of simulated values of hydrological components to landscape changes at a basin scale and examination of temporal responses in channel discharge with changes in landscape patterns (Hernandez et al., 2000; Miller et al., 2002; Liu et al., 2008a, b; Franczyk and Changk, 2009; Ghaffari et al., 2009; Mohammed et al., 2009). However, most studies do not quantify contributions of change for individual landscape element to different hydrological responses and few studies address the differences of hydrological components in different geographic characteristics, such as elevation.

The objective of this paper is to analyze and understand the impact of mountain landscapes on water balance in arid regions of northwestern China. We selected the upper Heihe River watershed as the study area and tried to: (1) simulate and quantify the runoff production of each main landscape element including glaciers, grassland, forestland, shrubland, and barren in the upper Heihe River watershed; (2) understand the spatial and temporal distributions of water balance under current landscape conditions and confirm the major spatial distributions of water production; and (3) estimate the impact of landscape change in the watershed on the hydrological components using different scenarios.

\section{Study area}

The Heihe River basin is one of the three major inland river basins in the Hexi Corridor, a typical arid inland region in northwestern China. The Heihe River is the second largest inland river in China. The upper Heihe River watershed (Fig. 1), is the water source area of the Heihe River. With remarkable vertical zonality, the elevation in this area ranges from 1,700 to $5,066 \mathrm{~m}$ asl and the mean annual precipitation increases from about $250 \mathrm{~mm}$ in the low-mountain or hill zone to about $500 \mathrm{~mm}$ in the high-mountain zone. Snow remains unmelted all year round above $4,000 \mathrm{~m}$ asl and glaciers form above $4,500 \mathrm{~m}$ asl in the mountains. Melting water of glacier and snow compensates runoff effectively. The upper Heihe River watershed has an area of $10,009 \mathrm{~km}^{2}$ and lies between latitude $37^{\circ} 42^{\prime} \mathrm{N}$ and $39^{\circ} 06^{\prime} \mathrm{N}$ and longitude $98^{\circ} 30^{\prime} \mathrm{E}$ and $101^{\circ} 12^{\prime} \mathrm{E}$. The landscape elements include glaciers, grassland, forestland, shrubland and barren. These landscapes distribute at different elevations. The lower limit of forest is $2,000 \mathrm{~m}$ asl and the upper limit is above $4,000 \mathrm{~m}$ asl. About $98.9 \%$ of the forests in the upper Heihe River watershed are found at 2,000-4,000 m asl (Qin, 2011). The real forest coverage at 2,000-4,000 $\mathrm{m}$ asl is about $6.5 \%$, and about $73 \%$ of the total area of the upper Heihe River basin exist here. Grassland distributes at the elevations from 1,700 to $4,900 \mathrm{~m}$ asl and shrubland is at 2,900-5,066 $\mathrm{m}$ asl. The shady slopes develop into forests which mainly consist of Picea crassifolia and grassland which mainly consists of Polygonum viviparum, Carex atrata, Stipa and so on. The grassland, which mainly consists of Reaumuria soongorica, Sympegma regelu, Ceratoides latens, Achnatherum splendens and so on, is distributed on sunny slopes. The soil of the shady slopes belongs to the mountain forest sierozem soil group while that of the sunny slopes belongs to the mountain grassland castanozem soil group. 


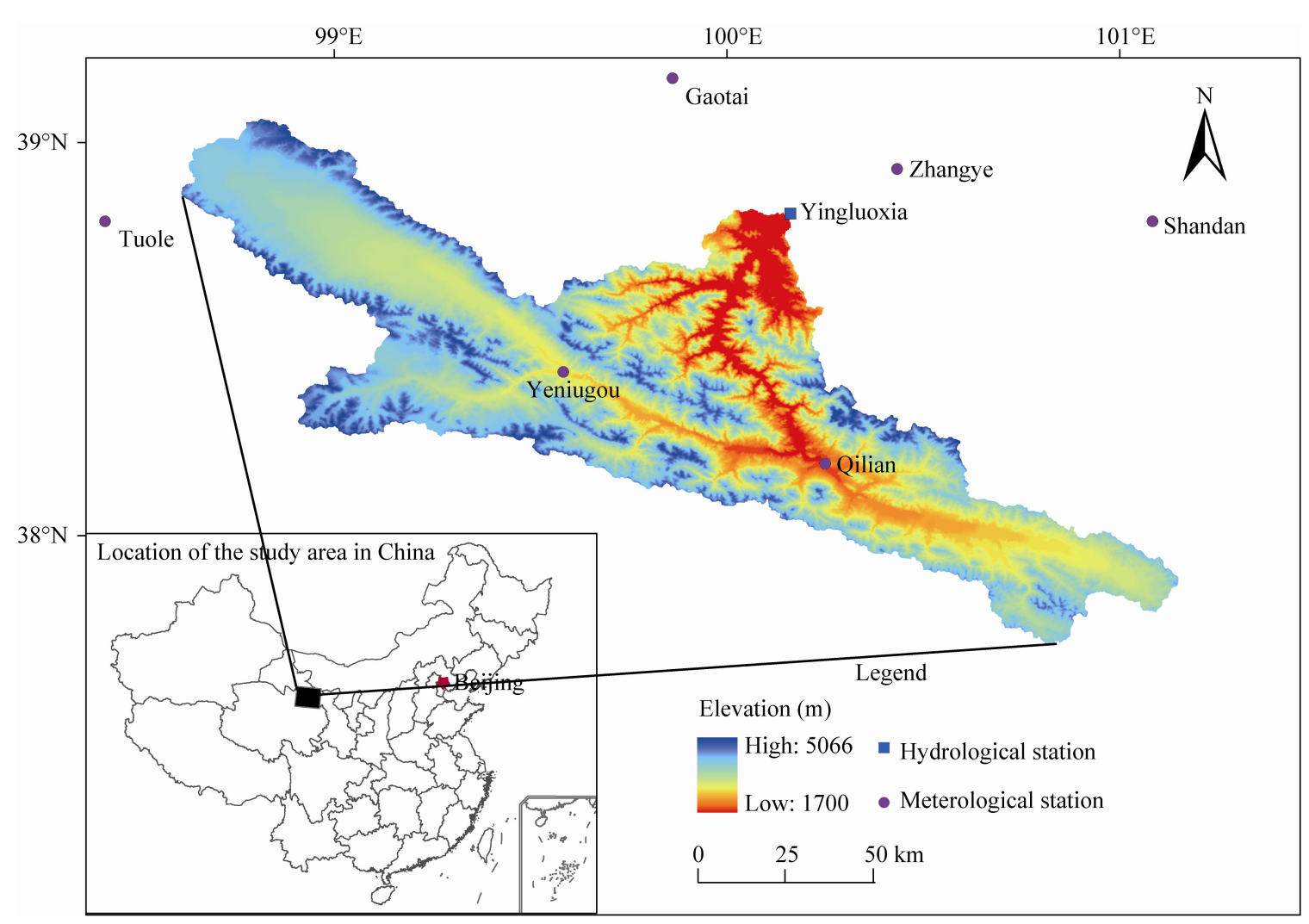

Fig. 1 A sketch of the upper Heihe River watershed

\section{Methods}

The VIC (Variable Infiltration Capacity) model was used to simulate runoff production and water balance components of each landscape element from 1997 to 2005 in the upper Heihe River watershed. Firstly, proportions of the runoff produced on the landscape at different elevations were simulated and calculated, along with the water storage capability and evapotranspiration at each elevation. Then we estimated the impact of landscape change in the watershed on the hydrological components using different scenarios.

\subsection{Model description}

The VIC model is a large-scale, semi-distributed hydrologic model (Liang, 1994). As such, it shares several basic features with the other land surface models commonly coupled to global circulation models ( $\mathrm{Li}$ ang, 1994; Nijssen et al., 2001). Considerable research has been conducted in recent years based on the VIC model, including studies on changes of water re- sources, influences of climate change on hydrological processes and the effects of landuse and landcover changes on hydrological components (Bowling and Lettenmaier, 1997; Nijssen et al., 1997; Lohmann et al., 1998a, b; Wood et al., 1998; Arnell, 1999a, b; Gleick, 1999).

Hydrological components simulated by the VIC model include evapotranspiration, surface runoff, base flow, canopy interception and soil water content. Evapotranspiration was calculated using the Penman-Monteith equation (Shuttleworth, 1993). Surface runoff was generated according to the variable infiltration curve. The main factors depend on the infiltration capacity, which represents the spatial distribution of surface soil moisture (Liang et al., 1994). Baseflow was generated according to an empirically based nonlinear soil moisture relationship (Liang et al., 1994). The effects of frozen soil on infiltration and runoff were represented using the method developed by Cherkauer and Lettenmaier $(1999,2003)$. Surface runoff and baseflow for each grid cell were routed to the basin outlet through a channel network as de- 
scribed by Lohmann et al. (1998a, b), and the fraction of each grid cell at the edge of the basin flowing into the basin was taken into account (Nijssen et al., 1997). The snowpack within the VIC model was modeled as two layers of variable thickness. Snowpack dynamics were simulated by an energy and mass-balance model (Cherkauer and Lettenmaier, 2003). The surface layer was used to represent the energy balance between the atmosphere and the snowpack, while the lower layer was used to solve processes within deeper snowpacks, and the lower layer was assumed to serve as storage for the excess snow mass derived from the thin surface layer (Wigmosta et al., 1994).

A number of modules exist for tailoring VIC simulations to a user's application, including Water Balance, Energy Balance, Frozen Soil and other modules. Users can select the modules they choose to run with the VIC model, based on the characters of the study area. The Water Balance Module assumes that the soil surface temperature is equal to the air temperature for the current time step and it does not solve the surface energy balance. By eliminating the ground heat flux solution and the iterative processes required to close the surface energy balance, the Water Balance Module needs significantly less computational time than other model modes (Cherkauer et al., 2003). Energy Balance Module solves the complete water balance but also minimizes the surface energy balance error. The surface energy balance is closed through an iterative process which tries to find a surface temperature that adjusts surface energy fluxes (sensible heat, ground heat, ground heat storage, outgoing longwave and indirectly latent heat) so that they compensate for incoming solar and longwave radiation fluxes. This module requires more computational time than Water Balance Module. However, it simulates the surface energy fluxes, which are important to understanding the hydrologic cycle and land surface-atmosphere interactions in a basin (Cherkauer et al., 2003). Frozen Soil Module adds the effects of soil ice content to both moisture and energy fluxes. It solves thermal fluxes at nodes through the soil column using the finite difference method (Cherkauer and Lettenmaier, 1999). In addition, it computes the maximum unfrozen water content at each soil node based on the nodal tempera- ture. Ice content for each soil moisture layer is then computed from the nodal values and is used to restrict infiltration and soil moisture drainage. The nodal ice contents are also used to derive the soil thermal conductivity and volumetric heat capacity for the next model time step. The frozen soil algorithm is computationally intensive but may play a major role in both the energy and water balance of cold regions (through seasonally frozen soil and permafrost). There are a few frozen areas in the study site, so the Frozen Soil Module was used in the VIC model.

Also, glaciers occur in the study site and glacial meltwater can effectively compensate runoff in summer. To accurately simulate the runoff in the upper Heihe River watershed, a glacier melting module was developed within the framework of the VIC hydrology model. Glacier melt is determined by the energy balance at the glacier-atmosphere interface, which is controlled by the meteorological conditions above the glacier and the physical properties of the glacier itself. A physically based approach to compute melt involves the assessment of the energy fluxes to or from the surface. When glacier surface temperature equals $0^{\circ} \mathrm{C}$, any surplus of energy at the glacier surface-air interface is assumed to be used immediately for melting. The main formula of the mass-balance model, Mass $\left(\mathrm{kg} / \mathrm{m}^{2}\right)$, is as follows:

$$
\text { Mass }=\int\left(\frac{E_{M}}{L_{M}}+P+\frac{Q_{S}}{L_{S}}\right) d t .
$$

Where, $E_{M}$ is the melt energy involved in melting $\left(\mathrm{W} / \mathrm{m}^{2}\right), \mathrm{P}$ is the snow accumulation $(\mathrm{m})$ and $\mathrm{Q}_{\mathrm{S}}$ represents the mass exchange due to sublimation $\left(\mathrm{W} / \mathrm{m}^{2}\right) . \mathrm{L}_{\mathrm{M}}$ is the latent heat of melting $\left(3.34 \times 10^{5}\right.$ $\mathrm{J} / \mathrm{kg}$ ), and $\mathrm{L}_{\mathrm{S}}$ is the latent heat of sublimation $\left(2.83 \times 10^{6} \mathrm{~J} / \mathrm{kg}\right) . \mathrm{E}_{\mathrm{M}}$ was calculated from the glacier surface-energy balance and can be expressed as:

$$
R_{N}+Q_{H}+Q_{S}+Q_{R}+Q_{G}+E_{M}=0 .
$$

Where, $R_{N}$ is net radiation $(\mathrm{W} / \mathrm{m}) ; \mathrm{Q}_{\mathrm{H}}$, the sensible heat flux $(\mathrm{W} / \mathrm{m})$; $\mathrm{Q}_{\mathrm{s}}$, the latent-heat flux $(\mathrm{W} / \mathrm{m}) ; \mathrm{Q}_{\mathrm{R}}$, the heat flux supplied by precipitation $(\mathrm{W} / \mathrm{m}) ; \mathrm{Q}_{\mathrm{G}}$, the ground heat flux in the ice or snow $(\mathrm{W} / \mathrm{m})$; and $\mathrm{E}_{\mathrm{M}}$, the energy consumed by melt $(\mathrm{W} / \mathrm{m})$. As commonly defined in glaciology, a positive sign indicates an energy gain to the surface while a negative sign signifies 
an energy loss. The glacier algorithm in the VIC model is described by adding one special land use/land cover class to the grid cell mosaic as well as the vegetation and bare soil land classes. Energy and mass balance of the glacier are resolved at each model time step. The glacier algorithm is based on the works of Hock et al. (2005) and Jiang (2008). We used glacier energy and mass-balance algorithm to calculate snow-melt runoff in the glacier ablation area and finally simulated river runoff using the convergence computing module to achieve hydrological processes in glacier-distributed river basins.

The VIC model could simulate components of water balance in each grid cell (5 minutes) of the study area. Water balance varies in different landscape types and can be calculated based on model simulation. Through analyzing distribution data (5 minutes) of each landscape type under the GIS software, and inputting them in the VIC model after converting them to the suitable file style, water balance of each landscape can be simulated.

\subsection{Model inputs}

The input data needed in the VIC model include the data from a digital elevation model (DEM), soil, vegetation and climate data, as well as digital glacier maps. The DEM was derived from the SRTM Digital Elevation Dataset (http://srtm.csi.cgiar.org/Index.asp) (Andy et al., 2008) with a resolution of 3 arc-second (about $90 \mathrm{~m}$ ). The soil data were derived from Global Soil Data Products CD-ROM (IGBP-DIS) which was downloaded from the Oak Ridge National Laboratory Distributed Active Archive Center with a resolution of one degree. The landscape data were mainly landuse data provided by the Environmental and Ecological Science Data Center for West China, National Natural Science Foundation of China (http://westdc.westgis. ac.cn/) (Ran et al., 2010) with a resolution of $1,000 \mathrm{~m}$. The climate data needed in the VIC model include daily values of precipitation, wind speed and mean, minimum and maximum air temperature. Except precipitation data, the other data were derived from seven national weather stations located in or near the Heihe River watershed (Fig. 1). Daily precipitation (with a resolution of 0.25 degree) was derived from Aphrodite's Water Resources (http://www.chikyu.ac. jp/precip/) (Yatagai et al., 2012). Glacier data were derived from the Chinese Glacier Inventory Dataset which had been produced by the WDC for glaciology and geocryology at Lanzhou (http://wdcdgg.westgis. ac.cn/) (Li et al., 2008). GIS was used to develop and manage some detailed data for accessibility, site, amenity factors required for the VIC model and other data preparation for the model inputs. For example, data were manipulated by extracting basin boundaries and producing flow directions with DEM data, resampling different digital maps to proper resolution (5 minutes) which the VIC model needed in this study and calculating the proportion of different landscape elements in each grid cell (5 minutes) and so on.

Vegetations have important impacts on the water balance, especially on evapotranspiration which consists of interception of vegetation, transpiration from the dry part of vegetation leaves and evaporation from soils. Vegetation parameters vary in vegetation types and change with seasons. Main parameters of vegetation including vegetation coverage rate (Veg), leaf area index (LAI), vegetation height $\left(\mathrm{h}_{\mathrm{c}}\right)$, root depth (lr), albedo (ALB), rough (ROU), zero-plane displacement $\left(\mathrm{d}_{\mathrm{z}}\right)$ and minimum stomatal resistance $\left(\mathrm{r}_{\mathrm{smin}}\right)$ are shown in Table 1. Based on these parameters, the VIC model can calculate the canopy interception and transpiration of vegetations in the study area (Monteith, 1973; Noilhan and Planton, 1989).

\subsection{Model calibration and validation}

Although the VIC model contains many parameters, including soil, vegetation, and snow, it is more appropriate to adjust some of these parameters during calibration. Main vegetation parameters input in the VIC model are shown in Table 1. Maximum air temperature at which snow can fall, minimum air temperature at which rain can fall and snow albedo are the most important parameters in snow algorithm of the VIC model. These parameters were set at $1.5^{\circ} \mathrm{C},-0.5^{\circ} \mathrm{C}$ and $0.9^{\circ} \mathrm{C}$, respectively. The soil parameters were most often adjusted during calibration of the VIC model and are significantly sensitive to the simulated results, including b_infilt, Dsmax, Ds, Ws and soil depth. B_infilt defines the shape of the Variable Infiltration Capacity curve. It describes the amount of available infiltration capacity as a function of relative saturated gridcell area. A higher value of $b$ _infilt gives 
Table 1 Vegetation parameters in the upper Heihe River Basin

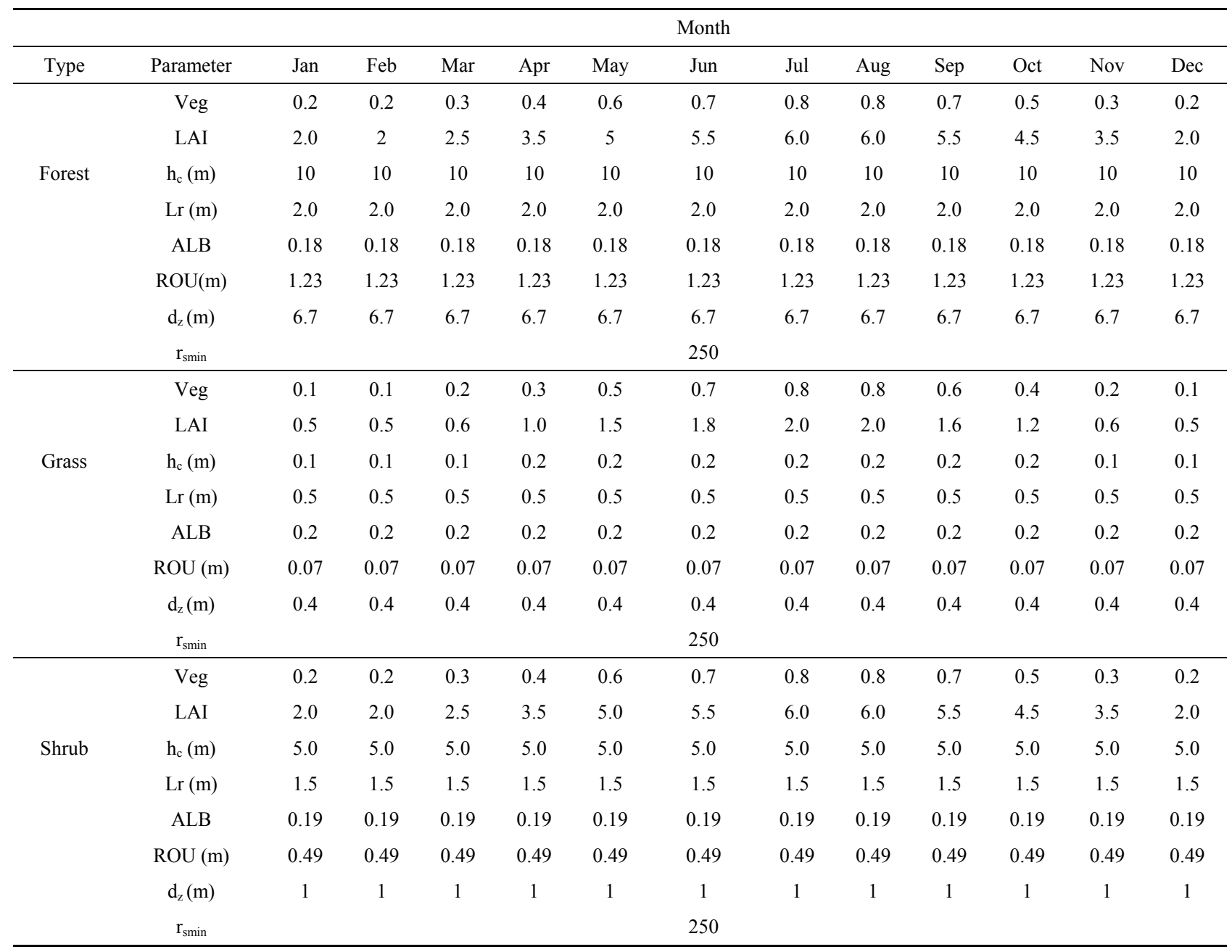

lower infiltration and yields higher surface runoff. Dsmax is the maximum baseflow that can occur from the lowest soil layer and depends on hydraulic conductivity. Ds is the fraction of Dsmax where non-linear (rapidly increasing) baseflow begins. With a higher value of Ds, the baseflow will be higher at lower water content in the lowest soil layer. Ws is the fraction of the maximum soil moisture (of the lowest soil layer) where non-linear baseflow occurs and a higher value of Ws will raise the water content required for rapidly increasing, nonlinear baseflow, which will tend to delay runoff peaks. These soil parameters were based on some research results in the Heihe River basin and adjacent regions (Jia et al., 2009; Zhao et al., 2012). Model calibration was performed by using the following procedures: 1) Dsmax and Ds were calibrated to fit the baseflow which oc- curred from the lowest soil layer; 2) b_infilt was adjusted to match the observed flow peaks, with a higher value chosen to give lower infiltration and yield higher surface runoff; 3) A higher value of Ws was chosen to raise the water content required for rapidly increasing, non-linear baseflow, which would tend to delay runoff peaks; and 4) The estimated value for the depth of the soil layers (d2, d3) was set, commonly with a deeper depth for arid regions and a lower depth for humid regions.

As the VIC model has no automated optimization function, it is difficult to make parameter optimization. The best daily simulation results were obtained by manual adjustment of parameters. Simulated runoff and observed runoff were compared in 1997-2001 (5 years) and 1997-2005 (9 years) respectively to reflect the stability of six optimal soil parameters. After the 
model adjustment, the values of $\mathrm{b}$ infilt, Dsmax, Ds, and Ws were set as 0.3, 8, 0.02 and 0.8, respectively in the research. Based on the adjusted values of soil parameters, the VIC model got satisfactory simulated results in the two time series. The optimal parameters are stable in the simulation.

Based on these model parameters analyzed above, the data in 2002 were used to calibrate the model. Glacier, soil and climate data in 2002 and land use data in 2000 were input to the VIC model to simulate the actual runoff in 2002. Observed runoff at the catchment outlet, Yingluoxia hydrological station (Fig. 1) in 2002 was used to calibrate the model. In order to verify the applicability of the calibrated model, the paper compared simulated runoff with measured data in the Heihe River basin during two periods (1997-2001 and 2003-2005).

Except for model parameters, the impacts of the different options or modules in the VIC model need to be estimated. The most commonly used control file options in the VIC model are FULL ENERGY, which determines whether VIC will iterate to find the surface temperature that balances the energy budget and FROZEN SOIL, and will simulate the phase change of water in the soil. In this study, simulated runoff was compared as a condition to help decide whether the FULL ENERGY or FROZEN SOIL was used or not. As no glacier module was embedded in the VIC model while glaciers were widely distributed in the study area (Yang, 1990), a Glacier Melting Module was added to the VIC model to simulate the compensation for runoff from glacial melting.

As glacier, frozen soil and the water-energy balance have important impacts on the hydrological process in the study area, respectively analyzing the effects of Glacier Module, Frozen Soil Module and Full Energy Module on runoff was needed in the study. It is essential to verify whether these modules in the VIC model could significantly improve simulation accuracy. In order to test the sensitivity and reliability of each module, a comparison was made between observed monthly runoff and estimated monthly runoff by the VIC model considering different conditions in the upper reaches of Heihe River basin. Based on the comparison, an optimal simulation scheme and combina- tion model form of the VIC model could be selected. Those simulation conditions included: 1) Glacier Module was included/excluded while the Full Energy and Frozen Soil modules were closed; 2) Full Energy Module was open/closed while the Glacier Module was included and the Frozen Soil Module was closed; 3) Frozen Soil Module was open/closed while the Glacier Module was included and the Full Energy Module was open; and 4) Full Energy Module was open all the time and the Frozen Soil Module was open from mid-June to September and closed at other time while the Glacier Module was included (Table 2).

Table 2 Different simulation conditions of the modules used or unused in the VIC model

\begin{tabular}{|c|c|c|c|c|}
\hline & $\operatorname{Sim} 1$ & $\operatorname{Sim} 2$ & $\operatorname{Sim} 3$ & $\operatorname{Sim} 4$ \\
\hline Glacier Module & $\mathrm{Y} / \mathrm{N}$ & Y & $\mathrm{Y}$ & $\mathrm{Y}$ \\
\hline $\begin{array}{l}\text { Full Energy } \\
\text { Module }\end{array}$ & $\mathrm{N}$ & $\mathrm{Y} / \mathrm{N}$ & $\mathrm{Y}$ & $\mathrm{Y}$ \\
\hline $\begin{array}{l}\text { Frozen Soil } \\
\text { Module }\end{array}$ & $\mathrm{N}$ & $\mathrm{N}$ & $\mathrm{Y} / \mathrm{N}$ & $\begin{array}{l}\text { Y (from mid-June to } \\
\text { September); } \\
\mathrm{N} \text { (other times in a year) }\end{array}$ \\
\hline
\end{tabular}

Note: Sim, simulation; Y, used; N, unused.

The simulated hydrological results showed differences when different model options or modules were adopted based on the model default parameters. Three criteria were used to evaluate the simulated results: Nash-Sutcliff (NS) coefficient (Nash and Sutcliffe, 1970), coefficient of determination $\left(R^{2}\right)$ and percent bias (PBIAS). The calibration/validation performance for the VIC model is considered acceptable when $R^{2}$ and NS are greater than 0.5 (Moriasi et al., 2007). The VIC model performance is satisfied when NS is larger than 0.5 , adequate when NS ranges from 0.54 to 0.65 , and very good when NS is larger than 0.65 (Moriasi et al., 2007). When the absolute value of PBIAS ranges from 15 to 25 , the VIC model is rated as satisfactory, good when from 10 to 15 , and very good when smaller than 10 (Moriasi et al., 2007).

\subsection{Model application}

2.4.1 Hydrological modeling in current conditions Landscape data in the study area mainly comprise seven landuse categories (glacier, forestland, shrubland, grassland, urban, barren and water). As water 
bodies and urban areas constitute a very small proportion of the total watershed and the two have been classified as "other", six categories were used in this modeling. The calibrated VIC model was used to simulate and quantify the runoff production of each main landscape element including glaciers, grassland, forestland, shrubland and barren, in the upper Heihe River watershed. The water balance of the study site was also estimated by the calibrated VIC model. Hydrological components at different elevations were simulated to confirm the major spatial distributions of water production.

2.4.2 Hydrological responses to landscape change scenarios

Because of excessive deforestation in the past decades, forest coverage in the upper Heihe River watershed decreased rapidly (Feng, 2008). The landscape change scenarios were developed while considering the regional guideline of "constructing water conservation forests, improving the ecological environment" and also based on both the growing conditions of vegetation and soil conservation guidelines of the Heihe River watershed. The shady slopes at the elevations between 2,000 and 4,000 m asl are mainly lands suitable for forest in the study area (Qin, 2011). Three landscape change scenarios were used in the study (Table 3): Scenario 1, converting all shady slope landscapes at 2,000-3,300 m asl to forestland; Scenario 2, converting all shady slope landscapes at 2,000-3,700 $\mathrm{m}$ asl to forestland; and Scenario 3, converting all shady slope landscapes at 2,000-4,000 asl to forestland (Fig. 2). The forest coverage rate in Scenario 1, 2 and 3 increased to $12.4 \%, 28.5 \%$ and $42.0 \%$, respectively. This study analyzed hydrological responses to three different landscape scenarios described above using the calibrated VIC model to analyze the hydrological effects of forest management changes in the upper Heihe River watershed.

\section{Results}

\subsection{Comparative results in different model condi- tions}

About $59 \mathrm{~km}^{2}$ of glacier exist in the upper Heihe River watershed and glacial meltwater can effectively supply the runoff (Yang, 1990). That is why we add a glacier module into the VIC model. The runoff was underestimated no matter whether the Glacier Module was included or excluded while the Full Energy and Frozen Soil modules were closed (Fig. 3a). It was clear in the warm season (from April to October) the estimated values with the Glacier Module were closer to observed values than in those scenarios which did not consider the Glacier Module (Fig. 3a). The simulated glacial meltwater made up about $3.6 \%$ of the total runoff in 2002, which is close to the results of $4.0 \%$ and $3.7 \%$ calculated by Gao and Yang (1985) and He et al. (2008), respectively.

Figure $3 b$ shows the change in monthly runoff depending on whether the Full Energy Module was open or not with glacial runoff included. When the Full Energy Module was open, there were visible increases in runoff. Monthly runoff increased by $7.6 \%$ on average when the Full Energy Module was open compared to when the Full Energy Module was closed (Fig. 3b). As there is a large amount of seasonal frozen soil and permafrost in the upper Heihe River watershed (Wang et al., 2001), we analyzed the influence of frozen soil on runoff. Figure $3 \mathrm{c}$ shows the simulated runoff results under the influence of frozen soil. Simulated

Table 3 Areal changes of landscape in three scenarios in the upper Heihe River basin

\begin{tabular}{|c|c|c|c|c|c|c|c|}
\hline \multirow{2}{*}{ Scenario } & \multicolumn{7}{|c|}{ Areal percentage of each landscape (\%) } \\
\hline & Forestland & $\begin{array}{l}\text { Grassland in } \\
\text { shady slope }\end{array}$ & $\begin{array}{l}\text { Grassland in } \\
\text { sunny slope }\end{array}$ & $\begin{array}{l}\text { Shrubland in } \\
\text { shady slope }\end{array}$ & $\begin{array}{l}\text { Shrubland in } \\
\text { sunny slope }\end{array}$ & $\begin{array}{c}\text { Barren } \\
\text { in shady slope }\end{array}$ & $\begin{array}{c}\text { Barren in } \\
\text { sunny slope }\end{array}$ \\
\hline Current & 6.5 & 23.4 & 27.2 & 8.6 & 3.4 & 16.6 & 14.1 \\
\hline Scenario 1 & 12.4 & 18.3 & 27.2 & 8.0 & 3.4 & 16.4 & 14.1 \\
\hline Scenario 2 & 28.5 & 11.6 & 27.2 & 2.1 & 3.4 & 12.9 & 14.1 \\
\hline Scenario 3 & 42.0 & 4.5 & 27.2 & 0.2 & 3.4 & 8.4 & 14.1 \\
\hline
\end{tabular}

Note: Scenario 1, converting all shady slope landscapes at 2,000-3,300 $\mathrm{m}$ asl to forestland; Scenario 2, converting all shady slope landscapes at 2,000-3,700 $\mathrm{m}$ asl to forestland; Scenario 3, converting all shady slope landscapes at 2,000-4,000 $\mathrm{m}$ asl to forestland. 

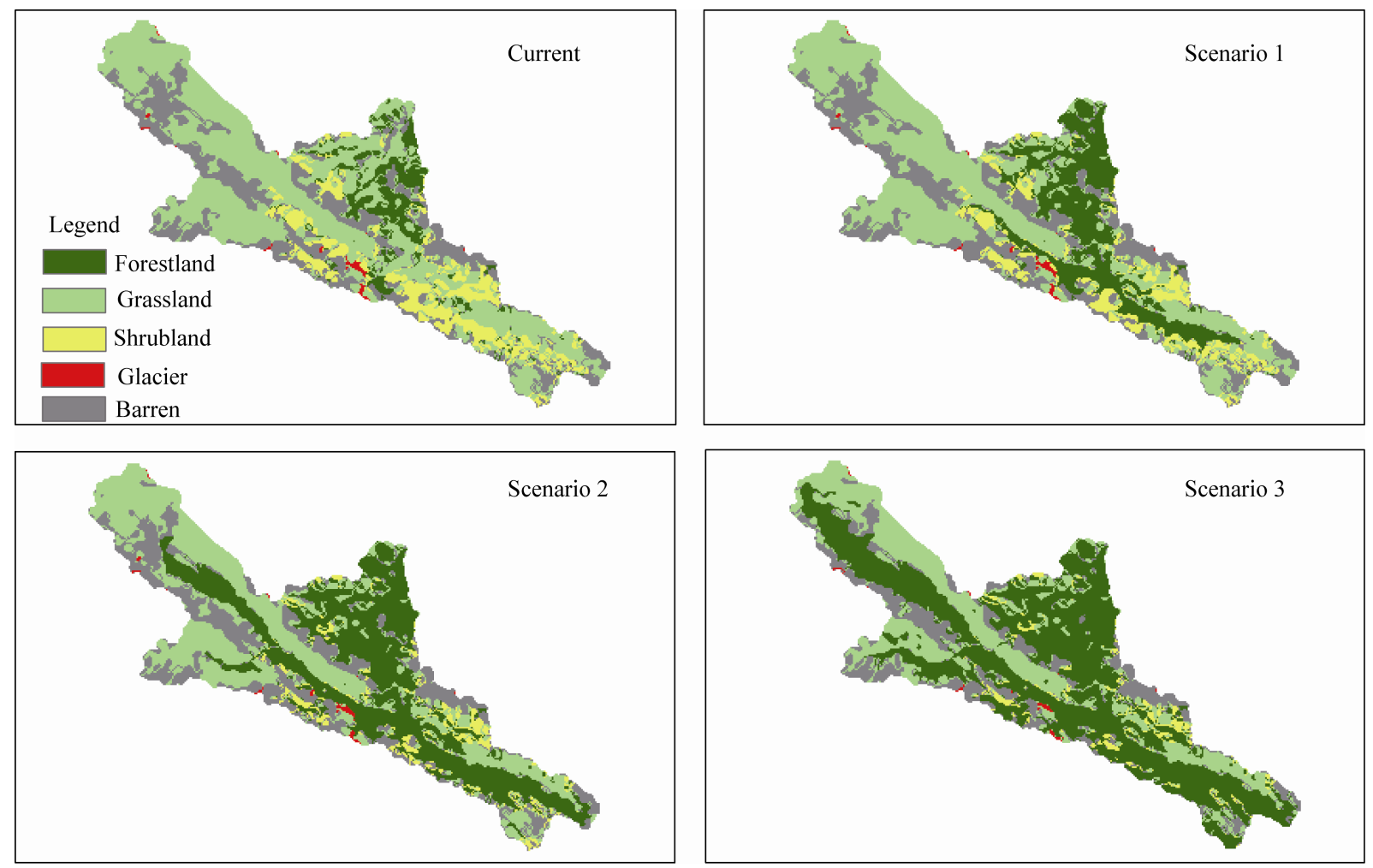

Fig. 2 Spatial distribution of scenarios in the upper Heihe river watershed with different forest landscapes
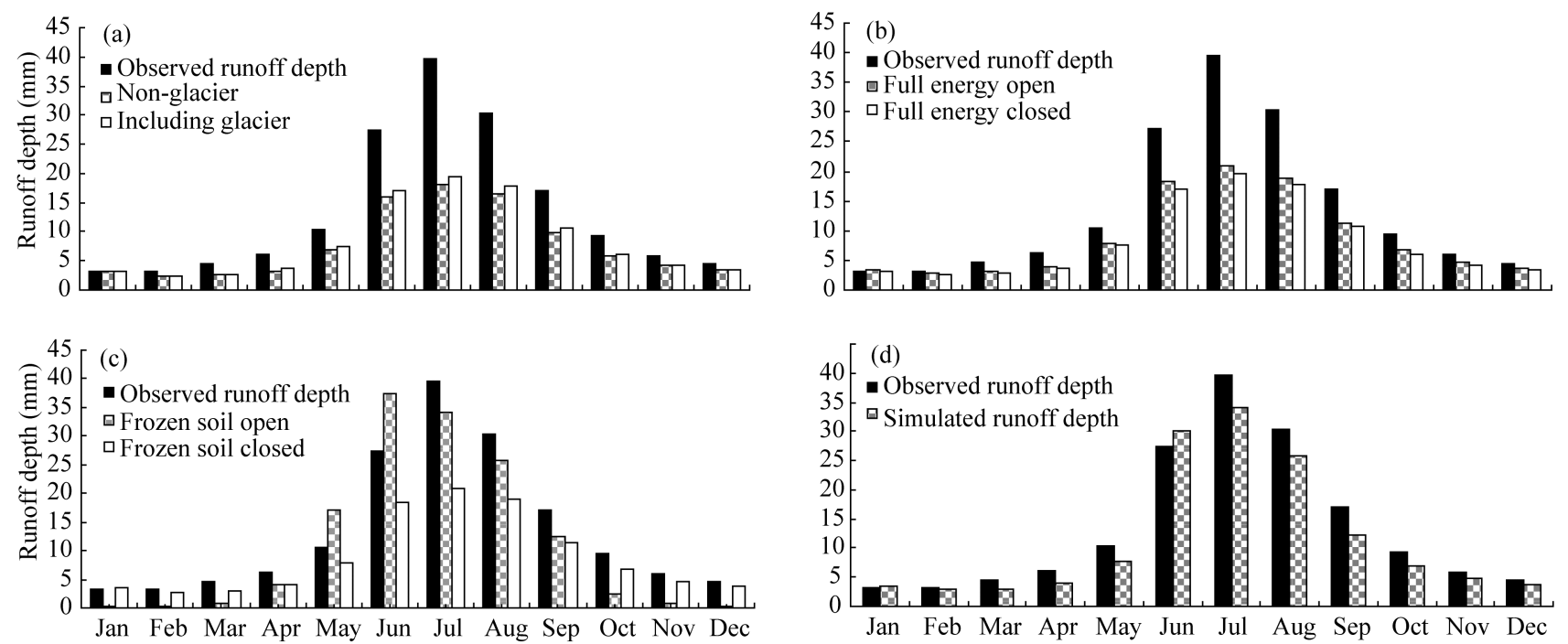

Fig. 3 Observed monthly runoff depth and estimated monthly runoff depth for excluding and including glacier runoff while Full-Energy Module and Frozen-soil module were closed (a); opening Full-Energy Module and closing Full-Energy Module with glacier runoff when Frozen-Soil Module was closed (b); opening Frozen-Soil Module and closing Frozen-Soil Module with glacier runoff when Full-Energy Module was open (c); and modeling with glacier runoff when Full-Energy Module was open and Frozen-Soil Module was open from June to September and closed at other time (d).

runoff in spring and winter was much smaller than the observed value, while the observed and actual amounts were nearly the same in summer when the Frozen Soil Module was open. Based on Figs. 3a-c, we concluded that properly applying the Full Energy, Frozen Soil and Glacier Melting modules were very important in simulating runoff accurately. Figure $3 \mathrm{~d}$ shows the monthly simulated runoff while using the 
Full Energy, Frozen Soil (during summer) and Glacier Melting modules; a good match can be seen between simulated and observed results. Table 4 lists daily values of $R^{2}$, NS and PBIAS for the calibrations. The VIC model was gradually optimized from Simulations (Sim) 1 to 4 . All $R^{2}$ values were above 0.7 and the corresponding linear slopes were $0.32,0.41,0.42$ and 0.77, respectively in $\operatorname{Sim} 1, \operatorname{Sim} 2, \operatorname{Sim} 3$ and $\operatorname{Sim} 4$. NS values became larger while PBIAS values became smaller gradually as this study progressed from Sim 1 to 4 . In the conditions during $\operatorname{Sim} 4, R^{2}$ and NS values were both above 0.5 and the PBIAS value was in the range of 15-25, suggesting satisfactory model performance (Moriasi et al., 2007). Considering the impact factors analyzed above, $\operatorname{Sim} 4$ is the optimal simulation condition after the calibration of the VIC model.

Table 4 Criteria for testing the accuracy of simulated runoff in different calibrating conditions

\begin{tabular}{ccccc}
\hline & $\operatorname{Sim} 1$ & $\operatorname{Sim} 2$ & $\operatorname{Sim} 3$ & $\operatorname{Sim} 4$ \\
\hline$R^{2}$ & 0.72 & 0.73 & 0.72 & 0.71 \\
NS & 0.31 & 0.49 & 0.52 & 0.67 \\
PBIAS & 51.30 & 36.15 & 32.21 & 18.99 \\
\hline
\end{tabular}

Note: Sim 1, Glacier Melting Module, Full Energy Module and Frozen Soil Module were all closed; Sim 2, Glacier Melting Module was open while Full Energy Module and Frozen Soil Module were closed; Sim 3, Glacier Melting Module and Full Energy Module were open while Frozen Soil Module was closed; Sim 4, Glacier Melting Module and Full Energy Module were open, and Frozen Soil Module was open from mid-June to September and closed at other time.

In order to verify the applicability of the optimal calibrated model, we compared simulated runoff with measured data in the upper Heihe River basin during two periods (1997-2001 and 2003-2005). The results were shown in Fig. 4. In 1997-2001, $R^{2}$ value was 0.67 , the correlation coefficient of the simulated and observed values reached 0.82 , and Nash-Sutcliff coefficient was 0.65 , which indicate that the simulated results were very satisfied. Though PBIAS coefficient was large (21.9), according to Moriasi et al. (2007), the simulation results could be accepted within the scope of 15-25. The simulated results using the calibrated VIC model were good in 1997-2001; in 2003-2005, $R^{2}$, Nash-Sutcliff coefficient and the value of PBIAS were $0.71,0.62$ and 7.2 , respectively, the simulation results were very good. The results simulated by calibrated model in both validation periods were good and the calibrated VIC model could meet the needs of this study. The calibrated VIC model in the condition of $\mathrm{Sim} 4$ was used in the simulated processes below.

\subsection{Water balance under current landscape con- ditions}

3.2.1 Spatial effects of landscape conditions on water distribution

Precipitation and temperature were associated with altitude change in the upper Heihe River watershed. Climate, evaporation, runoff and other water balance components varied significantly at different altitudes. It was hard to generate runoff in the lower elevations because of less precipitation and higher temperature, resulting in more evaporation, while the conditions of more precipitation and less evaporation in the alpine mountains resulted in a gradual increase in flow capacity. Also, the differences in the altitudes of the landscapes had a significant impact on water production. With different landscape structures, the functions of water consumption and conservation varied even under the same precipitation conditions. This resulted in the differences in the process of runoff formation. Figure 5 shows the contribution rates of runoff (CRR), generated in different landscapes at different elevations, compared to total runoff at the catchment outlet. It demonstrates the different landscape spatial distribution characteristics and the flow-producing capacity of each main landscape at different elevations.

Table 5 shows there are mainly three landscape types in the low mountains (1,700-2,900 m asl), while there are four types in the mid-mountain areas (2,900-4,000 $\mathrm{m}$ asl) and high mountains (above 4,000 $\mathrm{m}$ asl). Barren landscape plays the role of water production, while forestland and grassland consume water resources in the low mountains. Barren and grassland are the two main water production landscapes in the mid-mountain areas and generate $81.6 \%$ of the total runoff in this region (also $41.3 \%$ of the total runoff at the catchment outlet). Barren landscapes have the largest CRR (near 29.3\%) in the high mountains, followed by the grassland (14.3\%) and glacial land 


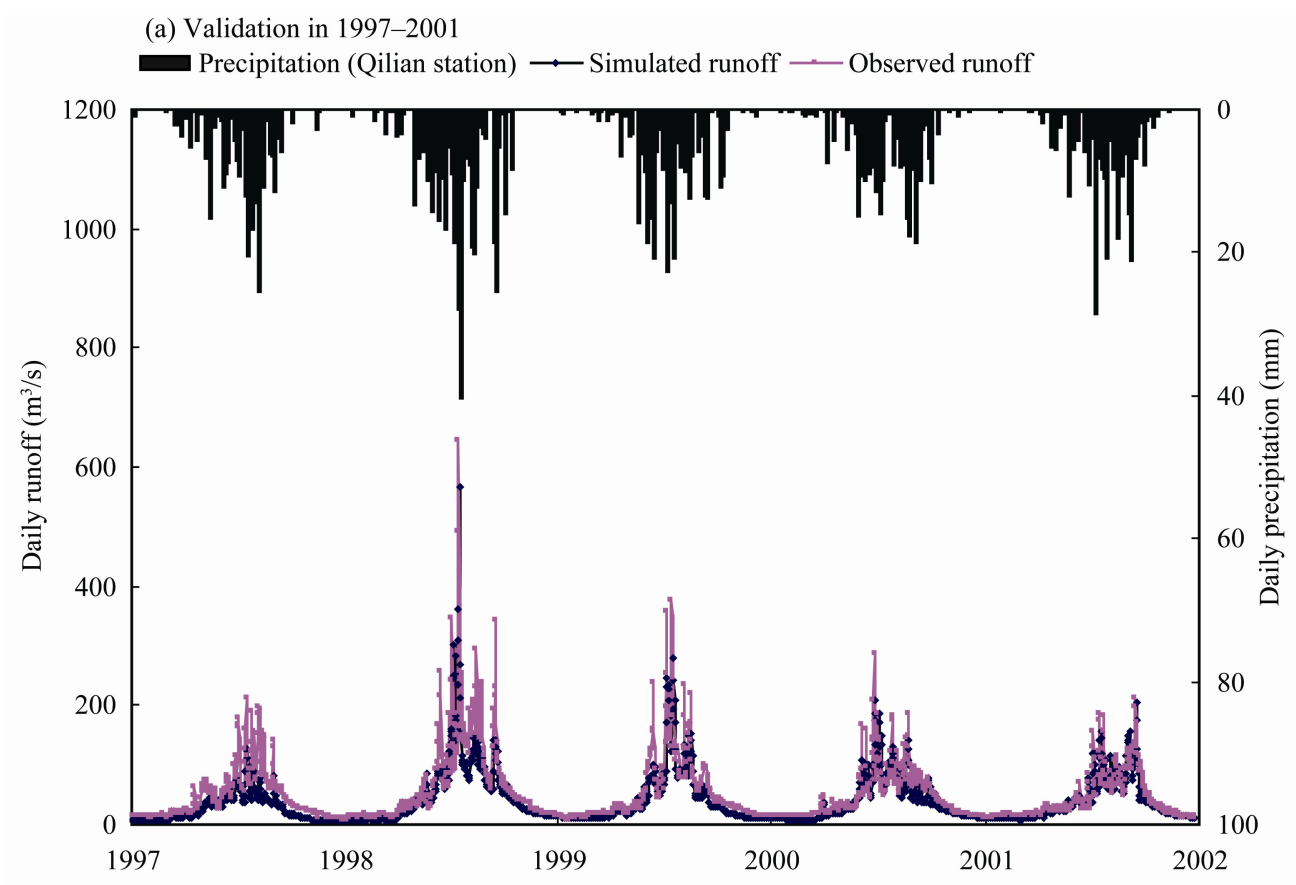

(b) Validation in 2003-2005

Precipitation (Qilian station) $\rightarrow$ Simulated runoff - Observed runoff

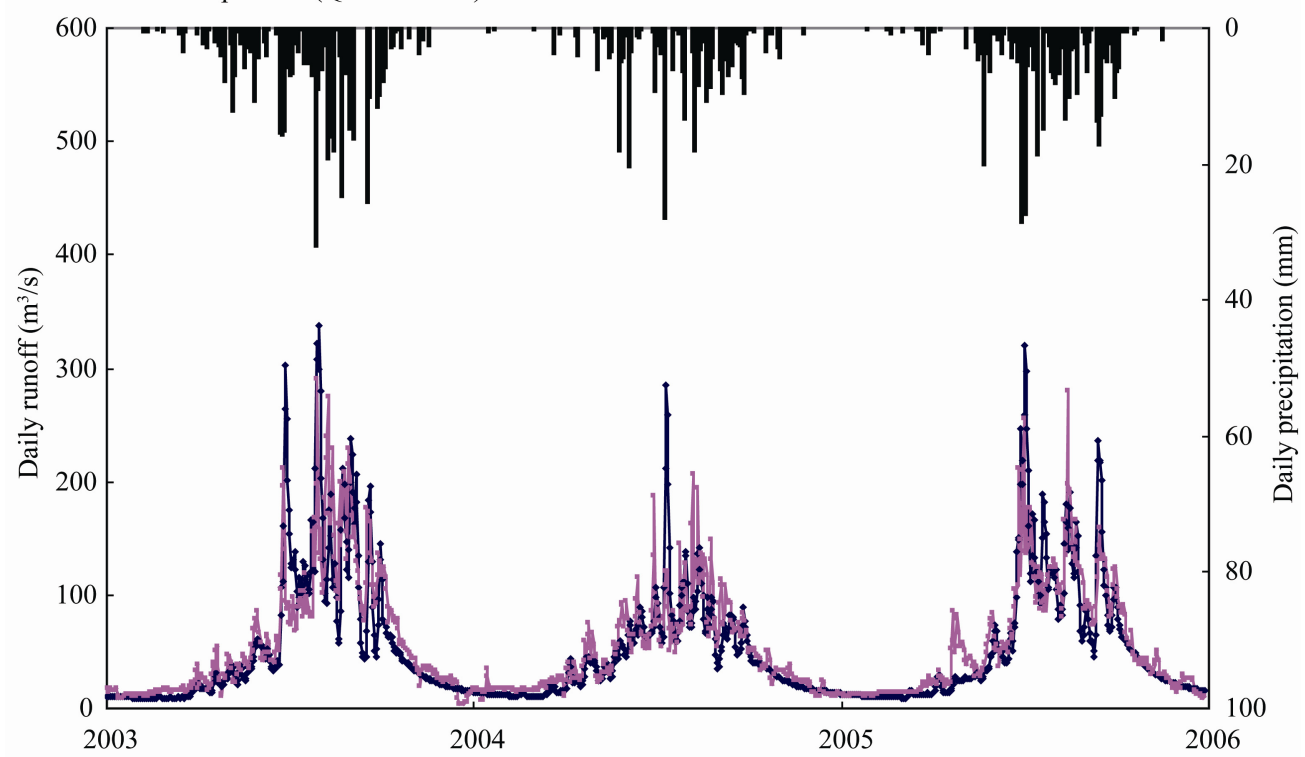

Fig. 4 Contrast of simulated runoff and measured data (Yingluoxia hydrological station) in the upper Heihe River basin during two periods of 1997-2001 and 2003-2005.

Table 5 Distributions and areal percentages of mountain landscape at different elevation

\begin{tabular}{cccc}
\hline & $1,700-2,900 \mathrm{~m}$ & $2,900-4,000 \mathrm{~m}$ & above $4,000 \mathrm{~m}$ \\
\hline $\begin{array}{c}\text { Landscape } \\
\text { type }\end{array}$ & $\begin{array}{c}\text { Forest }(1.49 \%) \text {, grassland }(3.84 \%), \\
\text { barren }(1.72 \%)\end{array}$ & $\begin{array}{c}\text { Forest }(4.96 \%) \text {, grassland (36.04\%), } \\
\text { shrubland }(11.52 \%), \text { barren (13.37\%) }\end{array}$ & $\begin{array}{c}\text { Grassland (10.68\%), shrubland (0.39\%), } \\
\text { barren (14.98\%), glacier }(0.82 \%)\end{array}$ \\
\hline
\end{tabular}

scapes (3.6\%).Forest landscape exists mainly below an altitude of 4,000 $\mathrm{m}$ asl. Glaciers occur above 4,000 $\mathrm{m}$ asl and shrublandoccur above $2,900 \mathrm{~m}$ asl. Grassland and barren landscapes both occur at different altitudes in the study area. Water is mainly consumed in the low mountain region, a major runoff-producing region in 
mid-mountain zone producing about $50 \%$ of the total runoff at the catchment outlet. Glacial landscape also plays the role of water production like barren and grassland landscapes in high mountains. The increases of precipitation and decreases of evaporation function convert more forest and grassland landscapes from water consumption to water production, as the runoff capacity of forests and grasslands gradually increases with elevation.

About $98.3 \%$ of the runoff at the catchment outlet was generated above 2,900 $\mathrm{m}$ asl, which includes $92.5 \%$ of the total basin area in the upper Heihe River watershed (Fig. 5). We calculated that $76.7 \%$ of the runoff was generated above $3,600 \mathrm{~m}$ asl, which in- cludes $60.1 \%$ of the total basin area based on the simulated runoff from different elevations in the VIC models. The proportion is slightly smaller than the $80.2 \%$ found by analysis using stable isotope technique and two-component model (Wang et al., 2009) and the $83.0 \%$ calculated based on changes to precipitation and evapotranspiration at different altitudes (Kang et al., 2008).

3.2.2 Temporal distribution of current landscape

Table 6 shows the changes of each water balance component during the vegetative growing season (May-September) in the upper Heihe River watershed. Precipitation was $339.5 \mathrm{~mm}$ during the growing season and nearly $70 \%$ fell within June-August. Changes

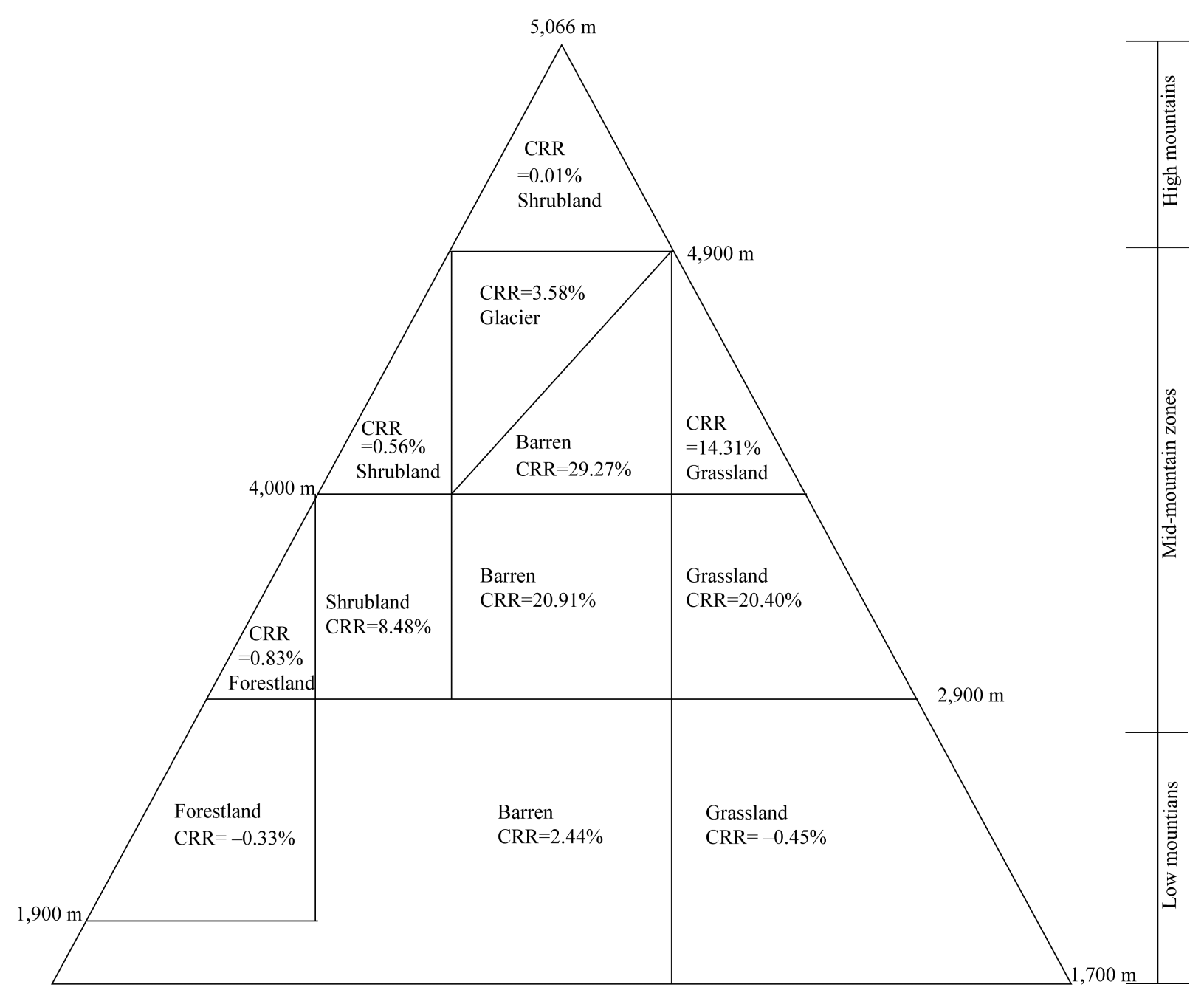

Fig. 5 The contribution rate of different landscapes to runoff at different elevations (CRR). The negative values mean water consumptions in that area while positive values mean water contributions. 
Table 6 Distribution of basinal water balance components and runoff coefficient in growing seasons in 1997-2005

\begin{tabular}{ccccccc}
\hline Month & $\begin{array}{c}\text { Precipitation } \\
(\mathrm{mm})\end{array}$ & $\begin{array}{c}\text { Interception } \\
(\mathrm{mm})\end{array}$ & $\begin{array}{c}\text { Transpiration } \\
\text { from vegetation }(\mathrm{mm})\end{array}$ & $\begin{array}{c}\text { Evaporation } \\
(\mathrm{mm})\end{array}$ & $\begin{array}{c}\text { Runoff depth } \\
(\mathrm{mm})\end{array}$ & $\begin{array}{c}\text { Runoff } \\
\text { coefficient }\end{array}$ \\
\hline May & 56.8 & 0.5 & 2.9 & 3.6 & 7.8 & 0.137 \\
Jun & 73.8 & 2.0 & 18.2 & 18.3 & 30.0 & 0.407 \\
Jul & 88.7 & 5.8 & 43.7 & 26.2 & 34.2 & 0.386 \\
Aug & 73.8 & 5.7 & 39.0 & 24.8 & 25.8 & 0.349 \\
Sep & 46.4 & 3.5 & 9.7 & 11.8 & 12.4 & 0.267 \\
Total & 339.5 & 17.5 & 113.5 & 84.8 & 110.2 & 0.325 \\
\hline
\end{tabular}

of interception, transpiration and evaporation were consistent with to precipitation. June had a large amount of runoff because this month received more precipitation and less water was consumed than in July or August. Although interception and evapotranspiration reached their lowest levels in May, runoff was less in May than in other months because May received less precipitation.

Also, the mean annual precipitation was $375.1 \mathrm{~mm}$, annual runoff depth was $138.3 \mathrm{~mm}$ and the calculated runoff coefficient was 0.37 in the upper Heihe River watershed. The runoff coefficient was comparable to the 0.360 and 0.347 calculated using other methods in this region (Kang et al., 2008; Wang et al., 2009). Table 6 shows the temporal change in the runoff coefficient. The runoff coefficient in June was larger (0.407) in the growing season. Although July and August had a large amount of precipitation, evapotranspiration and interception obviously experienced an increase at this time. The runoff coefficient during this period was smaller than that in June.

3.2.3 Water balance components of each main landscape

Table 7 lists hydrological components of different landscapes in the upper Heihe River watershed. Precipitation in barren landscape is larger than other landscapes in the upper Heihe River watershed, because barren exists mainly in the alpine mountains with more precipitation. Forest has higher levels of canopy interception and evapotranspiration than other landscapes, accounting for $24.5 \%$ and $77.1 \%$ of the total precipitation, respectively. While shrubland has less canopy interception and evapotranspiration compared with other landscapes, and levels of precipitation here are also smallest. Potential runoff in forestland is a negative value, which means the precipitation here cannot offset the water consumed by interception and evapotranspiration, and it is difficult for runoff to form under these conditions. Barren has the largest potential runoff (potential runoff coefficient is 0.69), followed by shrubland and grassland in the same area. Runoff yields of barren landscapes are the largest (52.46\% of the total runoff in the upper Heihe River watershed), followed by grassland $(34.15 \%)$, shrubland $(9.02 \%)$, glacier $(3.57 \%)$ and forest $(0.49 \%)$ (Fig. $6 b)$.

Table 7 Annual water balance components of different landscape in the upper Heihe River watershed in 1997-2005

\begin{tabular}{ccccc}
\hline & $\begin{array}{c}\text { Precipita- } \\
\text { tion (mm) }\end{array}$ & $\begin{array}{c}\text { Canopy inter- } \\
\text { ception }(\mathrm{mm})\end{array}$ & $\begin{array}{c}\text { Evapotranspira- } \\
\text { tion }^{*}(\mathrm{~mm})\end{array}$ & $\begin{array}{c}\text { Potential } \\
\text { runoff } \\
\text { yield }(\mathrm{mm})\end{array}$ \\
\hline Forestland & 337.53 & 82.72 & 260.37 & -5.56 \\
Grassland & 336.65 & 35.34 & 210.87 & 90.44 \\
Shrubland & 312.9 & 8.86 & 124.11 & 179.93 \\
Barren & 386.3 & 0 & 119.6 & 266.7 \\
\hline
\end{tabular}

Note: Evapotranspiration ${ }^{*}$ represents soil evaporation and vegetation transpiration.

\subsection{Hydrological effects of forest landscape change}

\subsubsection{Effect of forest change on runoff}

In Scenarios 1, 2 and 3, the forest coverage in the catchment increases to $12.4 \%, 28.5 \%$ and $42.0 \%$, respectively. The current forest coverage is $6.5 \%$, and about $5.9 \%, 22.0 \%$ and $35.5 \%$ of the catchment area in current conditions would change to a forested landscape in those three scenarios, respectively. The simulation shows that the runoff at the catchment outlet declines by $3.5 \%, 13.1 \%$ and $24.2 \%$, respectively, under the three scenarios (Fig. 7). The contribution of individual landscape type to flow at the catchment outlet varied in each landscape change scenario (Fig. 8). Although the area of forestland increases from 6.5\% (current forest cover) to $42 \%$ (forest coverage in Scenario 3 ) of the total catchment area, the contribution of forest landscape to discharge at the catchment outlet only increases from $0.5 \%$ to $14.1 \%$ because of the higher water use efficiency for trees. 

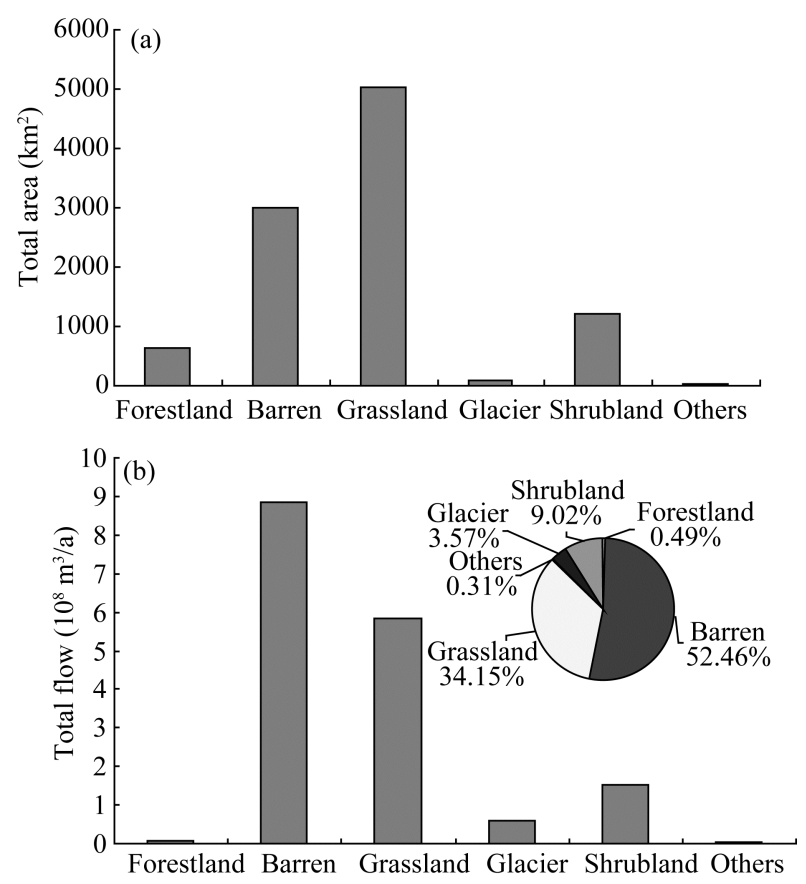

Fig. 6 Total areas (a) and annual runoff yields and percentages of different landscapes (b) in the upper Heihe River watershed in 1997-2005

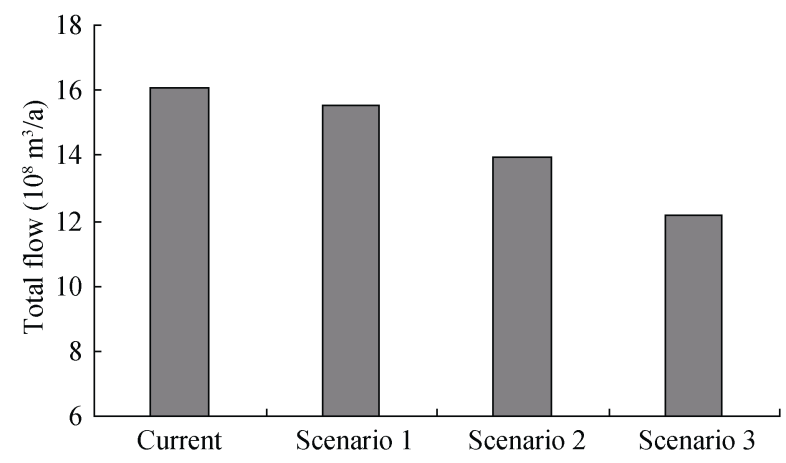

Fig. 7 Annual runoff at catchment outlets in the current land scape condition and all landscape change scenarios

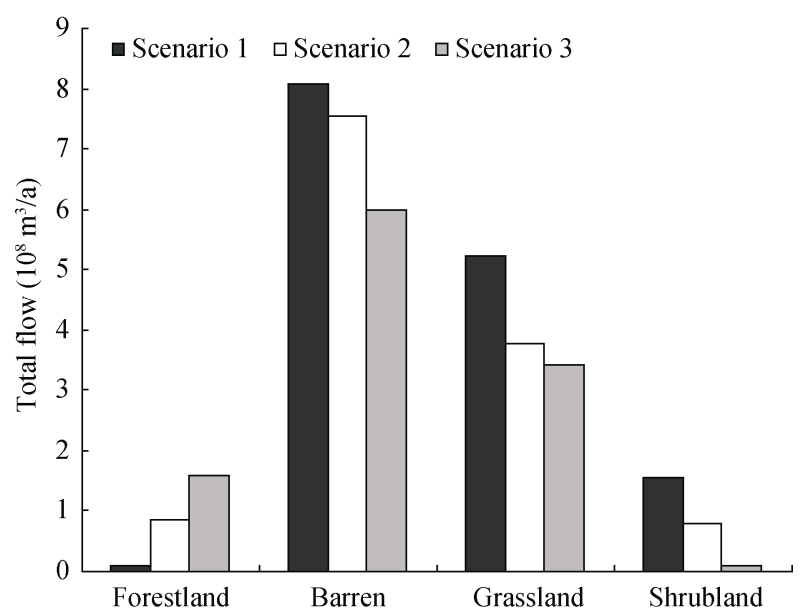

Fig. 8 Total flow from each of the three landscape change scenarios

\subsubsection{Effect of forest change on flooding}

The impact of forests on peak flow is very important in soil and water conservation. Table 8 compares flood peak reduction rates of forest landscapes in different scenarios. The flood peak reduction rate is $10.31 \%$ in Scenario 1 and increases to $26.8 \%$ in Scenario 3 when forest coverage increases to $42.0 \%$. With the increasing of forest coverage, the process of confluence slows and the peak discharge decreases while evapotranspiration increases (Fig. 9). Forests play the role of reducing flood peaks, increasing the baseflow and adjusting the runoff in the study area. Though annual runoff decreases with increased forest coverage, forests are effective in reducing soil erosion and in promoting water conservation.

Table 8 The influences of landscape in different scenarios on flood peak in the upper Heihe River watershed in 2002

\begin{tabular}{|c|c|c|c|c|c|c|c|}
\hline \multirow[b]{2}{*}{ Date } & \multirow{2}{*}{$\begin{array}{l}\text { Observed } \\
\text { flood peak } \\
\left(\mathrm{m}^{3} / \mathrm{s}\right)\end{array}$} & \multicolumn{2}{|c|}{ Scenario 1} & \multicolumn{2}{|c|}{ Scenario 2} & \multicolumn{2}{|c|}{ Scenario 3} \\
\hline & & $\begin{array}{c}\text { Simulated } \\
\text { flood peak }\left(\mathrm{m}^{3} / \mathrm{s}\right)\end{array}$ & $\begin{array}{c}\text { Peak reduction } \\
(\%)\end{array}$ & $\begin{array}{c}\text { Simulated } \\
\text { flood peak }\left(\mathrm{m}^{3} / \mathrm{s}\right)\end{array}$ & $\begin{array}{l}\text { Peak reduc- } \\
\text { tion }(\%)\end{array}$ & $\begin{array}{c}\text { Simulated } \\
\text { flood peak }\left(\mathrm{m}^{3} / \mathrm{s}\right)\end{array}$ & $\begin{array}{l}\text { Peak reduc- } \\
\text { tion }(\%)\end{array}$ \\
\hline 19 May & 145.8 & 122.4 & 16.05 & 119.9 & 17.76 & 87.3 & 40.12 \\
\hline 10 Jun & 206.9 & 193.4 & 6.52 & 173.2 & 16.29 & 168.4 & 18.61 \\
\hline 23 Jun & 201.4 & 187.8 & 6.75 & 166.1 & 17.53 & 160.7 & 20.21 \\
\hline $13 \mathrm{Jul}$ & 280.2 & 250.7 & 10.53 & 238.0 & 15.06 & 211.1 & 24.66 \\
\hline 6 Aug & 180.6 & 161.0 & 10.85 & 152.6 & 15.50 & 131.3 & 27.30 \\
\hline 13 Aug & 153.2 & 136.1 & 11.16 & 128.1 & 16.38 & 107.4 & 29.90 \\
\hline Average & & & 10.31 & & 16.42 & & 26.80 \\
\hline
\end{tabular}

Note: Peak reduction $=($ Observed flood peak - Simulated flood peak in each scenario $) /$ Observed flood peak 


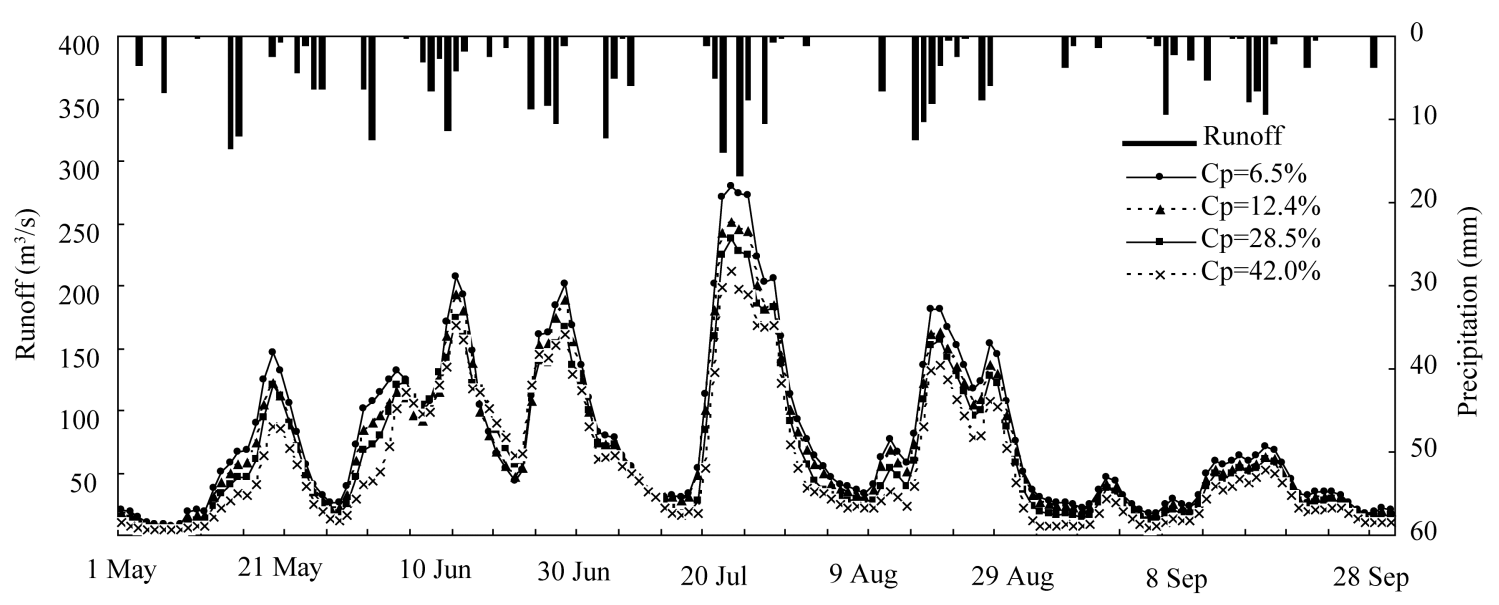

Fig. 9 Changes of daily runoff in different forest coverage scenarios in the upper Heihe River watershed in 2002

\section{Discussion}

Clearly, analyzing the spatial and temporal distributions of water balance components in mountainous areas is very important and has significant impact on the management and use of water resources. With the lack of measured data in mountainous areas, the model simulation is a good method for calculating hydrological changes in the distribution of water within the watershed. So choosing a correct model and reasonably simulating mountain water balance is particularly important.

The VIC model has many module options which operate with different effects, so it is very important to choose reasonable and correct modules to produce accurate modeling results. We chose the Full Energy Module instead of Water Balance Module to simulate the runoff and obtained a result close to actual values (Fig. 3b). The reason the Full Energy Module works well is it calculates the entire water balance but also minimizes the surface energy balance error. Under the Water Balance Module the landscape experiences higher evaporation, resulting in lower soil moistures and lower baseflows than observed values, while under the Full Energy Module the VIC model can calculate soil moistures and baseflows accurately and simulate hydrological results satisfactorily (Cherkauer et al., 2003).

A large number of areas with seasonally frozen soil and permafrost exist in the upper Heihe River watershed, with liquid and/or solid water in frozen soil
(Wang et al., 2001). The Frozen Soil Module was applied in the modeling, because it can effectively simulate the phase change of water in the soil (Luo et al., 2003). The simulated runoff calculated with the Frozen Soil Module was reasonable in summer (mid-June to September), but the results in spring and winter were unsatisfactory (Fig. 3c), which verified the conclusion that the frozen soil algorithm increases runoff in spring and decreases runoff in winter in the VIC model (Cherkauer and Lettenmaier, 1999). When the soil freezes, a portion of the soil moisture is converted to ice. The ice is unable to drain through the soil, so it is stored throughout the winter. With the frozen soil algorithm, VIC stops the unfrozen soil moisture draining and causes lower winter baseflow. The larger spring runoff simulated by the VIC model with the frozen soil algorithm, which compared with the real spring runoff, was caused by a combination of two processes: snowmelt being forced to leave the basin as runoff when it cannot infiltrate into the frozen soil and the release of stored soil moisture when the ice in the soil melts (Cherkauer and Lettenmaier, 1999). As there is a large quantity of snow covers in spring and winter in the upper Heihe River watershed ( $\mathrm{Li}$ and Wang, 2008), the effects of runoff increasing (in spring) and runoff decreasing (in winter) are obvious with the frozen soil algorithm in the VIC model. Simulated baseflow in the winters decreased and peak flows in the spring increased when the Frozen Soil Module was applied in the study area. That is the main reason why the simulated runoff in spring and winter 
was unreasonable.

Mountains are the main water-forming regions in the inland river basin. The process of formation of mountain runoff is affected by the complex spatial and temporal heterogeneity of elevation, topography and the underlying surface. Elevation and terrain affect the distribution of mountainous precipitation, while the complex nature and heterogeneity of the underlying surface have direct impacts on the distribution of evapotranspiration in the process of mountain hydrological cycle. Precipitation and evapotranspiration in the mountains directly or indirectly affect the hydrological cycle and water balance.

The impact of landscape distributions on mountain water balance components has significant spatial and temporal differences in the study area. The differences are mainly caused by spatial and temporal changes of precipitation and temperature. Because little precipitation and considerable evapotranspiration occur at low altitudes, it is difficult for forestland and grassland to form surface runoff and these areas are the main water consumption regions. Forests and grasses here consumed about $0.78 \%$ of the total runoff at the catchment outlet (Fig. 5). More precipitation and lower temperature gradually appear as elevation rises. The capacity for evapotranspiration correspondingly weakens at higher elevations. Water consumption is smaller and precipitation compensation is higher at middle and high altitudes which have a greater water generation capacity. Runoff generated in the mid-elevation mountains was larger than that in the high mountains (Fig. 5), primarily because the total area of mid-elevation mountains $\left(6,585.4 \mathrm{~km}^{2}\right)$ is larger than the area covered by high mountains $\left(2,677.8 \mathrm{~km}^{2}\right)$.

The large area of barren landscape and their strong runoff-producing capacity (Fig. 6) may be the main reasons for barren landscape having large runoff yields. Total runoff yield of forestland is low in part because forests cover only a small part of the study area and low mountains have a high level of water consumption. Simply changing all landscape into barren will greatly increase the total runoff at the catchment outlet in the upper Heihe River watershed, if the only concern was the runoff yields. But water generation and water and soil conservation are important factors we need to consider. Mountain torrents or floods are always accompanied by soil erosion. As analyzed above, though annual runoff decreases as forest cover increases, forests are effective in strengthening landscape scale water conservation. Also, forests decrease peak flow which will reduce flooding downstream and so the creation of forests is a good option for the wise use of water resources.

\section{Conclusions}

Located in a cold region, the frozen soil and glaciers found in the upper reaches of Heihe River watershed have effects on the hydrological processes. By using the Frozen Soil Module in summer and adding a Glacier Melting Module, the VIC model used in this paper simulates hydrology much closer to the real conditions than other models. Also, the Full-Energy Module was used instead of Water Balance Module in the VIC model after comparative analysis. The results show the calibrated VIC model performed satisfactorily.

The impacts of landscape on water balance components in current and in different change scenarios were evaluated and quantified. In summary, we concluded:

(1) The mid-mountain zone $(2,900-4,000 \mathrm{~m}$ asl) produces about $50.6 \%$ of the total runoff at the catchment outlet and is the major runoff-producing region. The high mountain zone (above 4,000 $\mathrm{m}$ asl) produces most of the remaining runoff, or $47.7 \%$ of the total runoff. Water is mainly consumed in the low mountain region (1,700-2,900 $\mathrm{m}$ asl) because the trees and grasses in this area have higher water requirements. The function of forest and grassland landscapes changes from a role of water consumption to water production with the rise of elevation, because the runoff capacity of forest and grassland landscapes gradually increases.

(2) The mean annual precipitation was $375.1 \mathrm{~mm}$ in the study area. Annual runoff here was $138.3 \mathrm{~mm}$ and the calculated runoff coefficient was 0.37 in the upper Heihe River watershed. Precipitation was lower in May and June than in July and October, as were evapotranspiration and interception. Runoff coefficients in May and June had larger values (0.525 and 
0.547) than those in July and October (Table 6).

(3) The largest runoff yields $52.46 \%$ of the total runoff) were generated in the barren landscape and then followed by grassland (34.15\%), shrubland (9.02\%), glacier (3.57\%) and forest $(0.49 \%)$ in the upper Heihe River watershed. The runoff yield of forest landscape is limited. One reason is the low forest coverage in the study area and the other is high water consumption by forests in the low mountain area.

(4) Simply changing all landscapes into barren would greatly increase the total runoff at the catchment outlet in the upper Heihe River watershed, but this would create many other problems such as flooding disasters, soil erosion and so on. Forests play the role of reducing the peak of flooding, increasing the base flow and adjusting runoff in the study area. Alhough annual runoff decreases when forest covers increase, forests are effective in reducing soil erosion and strengthening water conservation efforts.

\section{Acknowledgements}

This work was funded by the National Natural Science Foundation of China (41130638), the key innovation project of the Chinese Academy of Sciences (KZCX2-YW-QN310) and the National Science and Technology Support Program (2013BAB05B03).

\section{References}

Andy J, Reuter H, Nelson A, et al. 2008. Hole-filled seamless SRTM data V4. Italy: International Centre for Tropical Agriculture. [2008-8-12]. http://srtm.csi.cgiar.org.

Arnell N. 1999a. A simple water balance model for the simulation of streamflow over a large geophysical domain. Journal of Hydrology, 217: 314-335.

Arnell N. 1999b. The effect of climate change on hydrological regimes in Europe: a continental perspective. Global Environment Change, 8: $5-23$.

Bowling L, Lettenmaier D. 1997. Evaluation of the effects of forest roads on streamflow in Hard and Ware Creeks, Washington. Technical Report No. 155, Seattle: Department of Civil Engineering, University of Washington.

Cheng G, Zhao C. 2008. An integrated study of ecological and hydrological processes in the inland river basin of the arid regions, China. Advances in Earth Science, 23(10): 1005-1012.

Cherkauer K, Lettenmaier D. 1999. Hydrologic effects of frozen soils in the upper Mississippi River basin. Journal of Geophysics Research, 104(D16): 19599-19610.
Cherkauer K, Bowling L, Lettenmaier D. 2003. Variable infiltration capacity cold land process model updates. Global and Planetary Change, 38: 151-159.

Cherkauer K, Lettenmaier D. 2003. Simulation of spatial variability in snow and frozen soil. Journal of Geophysics Research, doi: 10.1029/2003JD003575.

Feng G. 2008. The influences of human activities on forest losses in the Qilian Mountain since the periods of Republic of China. Research of Qaidam Development, 1: 32-34.

Franczyk J, Changk H. 2009. The effects of climate change and urbanization on the runoff of the rock creek basin in the Portland metropolitan area, Oregon, USA. Hydrological Processes, 23: 805-815.

Gao Q, Yang X. 1985. The Features of Interior Rivers and Feeding of Glacial Melt Water in the Hexi Region, Gansu Province. Memoirs of Lanzhou Institute of Glaciology and Cryopedology Chinese Academy of Science (Glacier Variation and Utilizations in Qillan Mountains), No. 5. Beijing: Sciences Press, 131-141.

Ghaffari G, Keesstra S, Ghodousi J, et al. 2009. SWAT-simulated hydrological impact of land-use change in the Zanjanrood Basin, Northwest Iran. Hydrological Processes, doi: 10.1002/hyp.7530.

Gleick P. 1999. Study from the water sector of the national assessment. Journal of American Resource Association, 35: 1297-1300.

He J, Song G, Jiang X, et al. 2008. Relation between glacial melt water runoff and mountainous runoff in 2006 in four typical river basins of Heihe River water system. Journal of Desert Research, 28: 1186-1189.

Hernandez M, Miller S, Goodrich D, et al. 2000. Modeling runoff response to land cover and rainfall spatial variability in semi-arid watersheds. Environmental Monitoring and Assessment, 64: 285-298.

Hock R, Jansson P, Braun L. 2005. Modeling the response of mountain glacier discharge to climate warming. In: Reasoner M A. Global Change and Mountain Regions. Springer: Netherlands, 243-252

Jia Y, Ding X, Qin C, et al. 2009. Distributed modeling of landsurface water and energy budgets in the inland Heihe river basin of China. Hydrological Earth System Sciences, 13: 1849-1866.

Jiang X. 2008. Model study of the surface energy and mass balance of July $1^{\text {st }}$ Glacier at Qilian Mountains in China during the summer ablation period. Ph.D. Dissertation. Beijing: Chinese Academy of Sciences.

Kang E, Chen R, Zhang Z, et al. 2008. Some problems facing hydrological and ecological researches in the mountain watershed at the upper stream of an inland river basin. Advance Earth Sciences, 23: 675-681.

Li H, Wang J. 2008. The snowmelt runoff model applied in the upper Heihe River Basin. Journal of Glaciology and Geocrylogy, 30(5): 769-775.

Li X, Cheng G, Jin H, et al. 2008. Cryospheric change in China. Global and Planetary Change, 62: 210-218. 
Liang X. 1994. A two-layer variable infiltration capacity land surface representation for general circulation models. Water resources series, Tech. Report No. 140, University of Washington: Department of Civil Engineering.

Liu Y, Gupta H, Springer E, et al. 2008a. Linking science with environmental decision making: experiences from an integrated modeling approach to supporting sustainable water resources management. Environmental Modeling and Software, 23(7): 846-858.

Liu Y, Mahmoud M, Hartmann H, et al. 2008b. Formal scenario development for environmental impact assessment studies. In: Jakeman A, Voinov A, Rizzoli A, et al. Environmental Modeling, Software and Decision Support: Developments in Integrated Environmental Assessment, Elsevier: Amsterdam, 3: 145-162.

Lohmann D, Raschke E, Nijssen B, et al. 1998a. Regional scale hydrology: I. Formulation of the VIC-2L model coupled to a routing model. Hydrological Sciences Journal, 43: 131-141.

Lohmann D, Raschke E, Nijssen B, et al. 1998b. Regional scale hydrology: II. Application of the VIC-2L model to the Weser River, Germany. Hydrological Sciences Journal, 43: 143-158.

Luo L, Robock A, Vinnikov K, et al. 2003. Effects of frozen soil on soil temperature, spring infiltration, and runoff: results from the PILPS 2(d) experiment at Valdai, Russia. Journal of Hydrometeor, 4: 334-351.

Messerli B, Viviroli D, Weingartner R. 2004. Mountains of the world: vulnerable water towers for the $21^{\text {st }}$ century. Contribution to the Royal Colloquium on Mountain Areas, Abisko 2003. AMBIO Special Report, 13: 29-34.

Miller S, Kepner W, Mehaffey M, et al. 2002. Integrating landscape assessment and hydrologic modeling for land cover change analysis. Journal of the American Water Resources Association, 38(4): 915-929.

Mohammed M, Liu Y, Hartman H, et al. 2009. A formal framework for scenario development in support of environmental decision-making. Environmental Modeling and Software, 24(7): 798-808.

Monteith J. 1973. Principles of Environmental Physics. London: Edward Arnold Publishers, 241.

Moriasi D, Arnold J, Van Liew M, et al. 2007. Model evaluation guidelines for systematic quantification of accuracy in watershed simulations. Transactions of the Asabe, 50: 885-900.

Nash J E, Sutcliffe J V. 1970. River flow forecasting through conceptual models, Part I-A discussion of principles. Journal of Hydrology, 10: 282-290.

Nijssen B, Lettenmaier D, Liang X, et al. 1997. Streamflow simulation for continental scale river basins. Water Resource Research, 33: 711-724.

Nijssen B, O’Donnell G, Hamlet A, et al. 2001. Hydrologic sensitivity of global rivers to climate change. Climate Change, 50: 143-175.
Noilhan J, Planton S. 1989. A simple parameterization of land surface processes for meteorological models. Monthly Weather Review, 117: $536-549$.

Qin J. 2011. The regulate function of mountain forest landscape on fluvial runoff discharge in the arid areas of China. IEEE International Conference on Remote Sensing: Environment and Transportation Engineering. Nanjing: IEEE Conference Publications, 5546-5551.

Ran Y H, Li X, Lu L. 2010. Evaluation of four remote sensing based land cover products over China. International Journal of Remote Sensing, 31(2): 391-401.

Shuttleworth W. 1993. Evaporation. In: Maidment D R. Handbook of Hydrology. New York: McGraw Hill Inc.

Viviroli D, Weingartner R, Messerli B. 2003. Assessing the hydrological significance of the world's mountains. Mountain Research and Development, 23(1): 32-40.

Viviroli D, Weingartner R. 2004. The hydrological significance of mountains: from regional to global scale. Hydrology and Earth System Sciences, 8(6): 1016-1029.

Wang G, Yang L, Chen L, et al. 2005. Impact of land use changes on groundwater resources in the Heihe River basin. Journal of Geographical Sciences, 15(4): 405-414.

Wang J, Kang E, Jin B. 2001. Hydrological function of frozen soil in forest area in the upper reaches of the Heihe River. Journal of Northwest Forestry University, 16: 30-34.

Wang N, Zhang S, He J, et al. 2009. Tracing the major source area of the mountainous runoff generation of the Heihe River in northwest China using stable isotope technique. Chinese Science Bulletin, 16: 2751-2757.

Wigmosta M, Vail L, Lettenmaier D. 1994. A distributed hydrology-vegetation model for complex terrain. Water Resources Research, 30(6): 1665-1679

Wood E, Lettenmaier D, Liang X, et al. 1998. The project for intercomparison of land-surface parameterization schemes (PILPS) phase-2(c) Red-Arkansas River experiment: 1. Experiment description and summary intercomparisons. Journal of Global and Planetary Change, 19: 115-135.

Yang Z. 1990. Glacier Water Resources in China. Lanzhou: Gansu Science and Technology Press.

Yatagai, A, Kamiguchi K, Arakwa O, et al. 2012. APHRODITE: constructing a long-term daily gridded precipitation dataset for asia based on a dense network of rain gauges. Bulletin of American Meteorological Society 93: 1401-1415.

Zhao Q, Ye B, Ding Y, et al. 2012. Coupling a glacier melt model to the Variable Infiltration Capacity (VIC) model for hydrological modeling in north-western China. Environmental Earth Sciences, doi: 10.1007/s12665-012-1718-8. 